\author{
小児良性発作性めまい \\ 一片頭痛に関連した小児期特有のめまい症候群一
}

尾関 英德

\title{
Benign paroxysmal vertigo of childhood
}

\author{
Hidenori Ozeki \\ Department of Otolaryngology, Saitama Medical Center
}

片頭痛は緊張型頭痛とともに一次性頭痛の代表 的疾患であり, 発作性・拍動性の頭痛に悪心・嘔 吐や光・音に対する過敏性などを合併する（国際 頭痛分類第 2 版, The International Classification of Headache Disorders, 2 nd ed: ICHD-2 ${ }^{1) 22}$ 。片 頭痛患者にめまいを生じうることはこれまでにし ばしば指摘されている ${ }^{34)}$ 。一方で, 片頭痛は遺伝 性素因も強く関与しており, 若年期から発症する ことも多い。幼少期における片頭痛関連疾患の中 に, 周期的に嘔吐, 腹痛やめまいを生じ, 将来的 に片頭痛に移行する疾患群が存在する。これらは 「小児周期性症候群」と呼ばれており, このうち 反復性めまいを生じるものを「小児良性発作性め まい (Benign paroxysmal vertigo of childhood)」 として ICHD-2 ${ }^{12)}$ にその診断基準が記されている （表 1 ）。注意すべき点としては, 片頭痛関連例疾 患と定義づけられているにもかかわらず，めまい に伴う片頭痛発作は明瞭ではない，あるいは年齢 的に症状を正確に表現することが難しい場合があ ることである。このため心因性めまいや非定型的 めまい症として扱われている場合も多いと考えら れる。

小児良性発作性めまい (Benign paroxysmal vertigo of childhood, BPVC) という呼称は1964年 Basser $^{5)}$ により提唱され, ICHD-2にもこの疾患 名が記載されているが, 良性反復性めまい（Be-

埼玉医科大学総合医療センター耳鼻咽喉科 nign recurrent vertio, BRV) と表記されることも ある ${ }^{6)}$ 。尚, 良性発作性頭位めまい症 (Benign paroxysmal positional vertigo, BPPV) は名称が似て いるが，疾患概念は全く異なる。

以前著者らが19歳以下の若年者めまい症例131 例についてその疾患構成を調べたところ7), この 小児良性発作性めまいに該当する症例は15例 (11\%) であった。さらに全症例131例を年齢別に 分けて調べたところ，10歳以下の群32例において 本疾患は 8 例 $(25 \%)$ を占めており，本疾患は幼 少期により特徵的な疾患であることが確認され た。諸外国の医療機関を受診した若年者めまい疾 患における本疾患の割合は12-25.5\%で性差は特 に認められないとされており ${ }^{8)}$ われわれの報告 中でもほぼ同様の結果であった。

小児良性発作性めまいの典型的臨床像として は, 2-4 歳頃の幼少児に突然回転性めまいが発 症し嘔気・嘔吐を伴い反復するため, 心配した親 と共に小児科を受診することが多い。めまい発作 時, 幼少児では不安と恐怖のために母親や周囲に しがみつき, 症状を言葉で表現できないこともあ $ろ^{9)}$ 。精査目的に神経内科や耳鼻咽喉科に紹介さ れることもある。めまい発作は数秒から数分持続 して消失し, 発作頻度は月に 1-2 回程度が多い。 発作期に眼振を認めることもある。てんかん発作 と異なり意識消失は伴わない。蝸牛症状として耳 閉感や耳鳴を伴うことがあるが, 純音聴力検査な どでは難聴が確認されないことが特徽の一つでも 
ある。また片頭痛の臨床症状である, 音や光への 過敏性や頭部運動による症状の増悪を認める。乗 り物酔いの既往や，チーズ・チョコレートなどの 摂食による症状誘発, めまい後の傾眠傾向が認め られることもある。さらに家族歴として片頭痛の 既往がしばしば見られる。これらの症候は片頭痛 患者におけるものと類似しており，患児が成長と 共にしばしば片頭痛を起こすようになることも併 せて，本疾患は片頭痛関連疾患 (migraine equivalent）あるいは片頭痛への前駆状態（precursor） として位置づけられている。めまいの予後は比較 的良好で，発症から 1 年以内で約 $60 \% ， 3-4$ 年 以内で約 $90 \%$ のまいは消失し ${ }^{9)}$, 今度は片頭痛 発作が顕在化することも多い ${ }^{10}$ 。

本疾患におけるめまいの責任病巣に関しては, 末梢前庭障害 ${ }^{11)}$ および中枢前庭障害 ${ }^{10)}$ の関与は示 唆されているものの, 詳細は明らかにはなってい ない。疾患概念が提唱された当初は, 温度刺激検 查で一側または両側の中等度以上の半規管麻痺 (canal paresis, CP) が特徴的所見として報告され ていた ${ }^{5)}$ が，その後の諸家の報告では CP を特徴 的所見とすることには否定的である。また一側の 眼振方向優位性 (directional preponderance : DP）を認めるとする報告もある ${ }^{12)}$ 。われわれの 症例15例においても, 半規管麻疩, 発作間欠期の 自発眼振や頭振後眼振は認めなかった 対して, 成人における片頭痛性めまい（Migraneous vertigo）の検討では, 一部の症例で半規管麻 疩, 前庭性頸筋電位 (VEMP) 反応消失などの末 梢前庭障害を疑わせる所見を認めており ${ }^{13)}$ ，また 最近では片頭痛性めまいとメニエール病との関連 性に言及する報告もあり ${ }^{14)}$, 成人片頭痛性めまい の少なくとも一部には末梢前庭障害を持つ群が存 在すると考えられる。これら成人片頭痛性めまい と比較すると, 明らかな末梢前庭障害の所見を認 めない小児良性発作性めまいに関しては，末梢性 障害よりもむしろ中枢性障害の関与がより強いと も考えられる。

では片頭痛に関連するめまいの発症機序とは何 であろうか。最近，片頭痛そのものを生じさせる 病態が末梢あるいは中枢前庭神経系へ影響を及ぼ しているという観点から, 片頭痛性めまい発症機 序についての総説がまとめられている ${ }^{15)}$ 。それに よると，(1)血管収縮による中枢または末梢前庭の
表 1 ICHD-2 による小児良性発作性めまいの診断 基準

A. B一Dを満たす発作が 5 回以上ある。

B. 前触れなく生じ数分一数時間で自然軽快する, 頻回・重度の回転性めまい発作（注：眼振また は嘔吐を伴う場合が多い。片側性拍動性頭痛が めまい発作の際に生じることがある)。

C. 発作間欠期には神経所見および聴力・平衡機能 は正常。

D. 脳波所見は正常。

虚血，(2)拡延性抑制（spreading depression）に よる神経障害, (3)神経ペプチド放出による神経や 感覚器の障害, (4)感覚器障害に続発する内リンパ 水腫の進展, (5)アロディニア（異痛症）の場合の ように前庭系が感作されめまいが起きやすい状態 となっている, (6)インチャンネル異常などの遺 伝的素因，などが可能性として挙げられている。

小児良性発作性めまいにおいては, 2-4 歳頃 という心身未成熟期に発症し成長とともに消失す ること，片頭痛そのものが認められない場合もあ ることなどから, 成人型の片頭痛性めまいが小児 期に発症したものと単純には考えにくく，上記の 病態がそのまま当てはまるとは限らない。しかし 将来的に片頭痛に移行する素因を患児が内包して いることを考慮すると，片頭痛を生じさせる何ら かのメカニズムが本疾患の成立に寄与していると 想定される。

本疾患の治療に関しては，発症年齢が低く，ま た予後良好であることから，われわれの外来にお いては10歳以下の症例に対しては保存的経過観察 を基本方針としている。片頭痛を誘発する食物を 制限する必要性もあると考えられるが，実際には 困難な場合も経験する。症状が強く長期化する場 合や，心理性要素を合併するような場合には小児 科医（成長障害に詳しい医師が望ましい）と相談 の上，片頭痛治療あるいは急性期めまいに対する 投薬や心理学的療法を試みている。小児科医ある いは頭痛専門医の間でも本疾患や片頭痛性めまい に対する関心が高まっており，本疾患に関する耳 鼻咽喉科としての対応が求められる場合もある。 めまいに関する専門知識を持つ耳鼻咽喉科医のこ の領域への積極的な参入が望まれるところであ る。 


\section{文献}

1) 国際頭痛学会・頭痛分類委員会：国際頭痛分 類第 2 版（ICHD-II）。 日頭痛会誌 $31 ： 13-$ 188, 2004

2 ) Headache classification subcomittee of the international headache society: The international classification of headache disorders; 2 nd edition. Cephalalgia 24 suppl 1:9-160, 2004

3 ) Neuhauser H, Lempert T: Vertigo and dizziness related to migraine: a diagnostic challenge. Cephalalgia 24: 83-91, 2004

4 ) Brantberg K, Trees N, Baloh RW: Migraineassociated vertigo. Acta Otolaryngol 125: 276-279, 2005

5 ) Basser LS: Benign paroxysmal vertigo of childhood (A variety of vestibular neuronitis). Brain 87: 141-152, 1964

6 ) Furman JM, Cass SP: Benign Recurrent Vertigo of Chilhood. In ed Furman JM, Cass SP. Vestibular Disorders- A case study approach$2^{\text {nd }}$ ed. pp 145-148, Oxford University Press, New York, 2003

7 ）尾関英徳, 岩崎真一, 室伏利久 : 若年性めま い症例の検討一良性反復性めまい（Benign Recurrent Vertigo）を中心として一. Equilibrium Res 67: 194-199, 2008

8 ) Erbek SH, Erbek SS, Yilmaz I, et al.: Vertigo in childhood: A clinical experience. Int J Pediatr Otorhinolaryngol 70: 1547-1554, 2006

9 ) Drigo P, Carli G, Laverda AM: Benign paroxysmal vertigo of childhood. Brain \& Development 23: 38-41, 2001

10) Lanzi G, Balottin U, Fazzi E, et al.: Benign paroxysmal vertigo of childhood: a long-term follow-up. Cephalalgia 14: 458-460, 1994

11) Eviatar L, Eviatar A: Vertigo in children: differential diagnosis and treatment. Pediatrics 59: 833-838, 1977

12) Cass SP, Furman JM, Ankerstjerne JKP, et al.: Migraine-related vestibulopathy. Ann Otol Rhinol Laryngol 106: 182-189, 1997

13) Iwasaki S, Ushio $M$, Chihara $Y$, et al. : Migraine-associated vertigo: clinical characteristics of Japanese patients and effect of lomerizine, a calcium channel antagonist. Acta Otolaryngol Suppl 127: 45-49, 2007

14) Murofushi $T$, Ozeki $H$, Inoue $A$, et al.: Does migraine-associated vertigo share a common pathophysiology with Meniere's disease? Study with vestibular-evoked myogenic potential. Cephalalgia 29: 1259-1266, 2009

15）室伏利久：片頭痛性めまい一その病態の解明 にむけて。耳鼻・頭頸外科 81：737745,2009 